\title{
Kultura organizacji w zakładach opieki zdrowotnej - analiza przekrojowa
}

https://doi.org/10.33141/po.2005.06.04

Iga Rudawska
Przegląd Organizacji, Nr 6 (785), 2005, ss. 18-21

www.przegladorganizacji.pl Towarzystwo Naukowe Organizacji i Kierownictwa (TNOiK)

\section{Wprowadzenie}

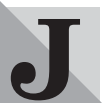

ednym z przejawów zmian systemowych zachodzących w polskim sektorze zdrowia jest oddzielenie funkcji dostawcy usług zdrowotnych od funkcji płatnika za te świadczenia. Pierwsza z funkcji w polskim sektorze zdrowia powierzona została publicznym i niepublicznym zakładom opieki zdrowotnej oraz praktykom lekarskim i pielęgniarskim, a druga - regionalnym oddziałom Narodowego Funduszu Zdrowia (przed 1 kwietnia 2003 r. zadanie to sprawowały kasy chorych), które negocjuja z wymienionymi podmiotami kontrakty na świadczenie usług zdrowotnych. Wprowadzony model - w zamierzeniu pomysłodawców - miał pobudzać konkurencję na wzór rozwiązań rynkowych.

Na szczególną uwagę zasługuje fakt, że gros podmiotów niepublicznych funkcjonowało już w warunkach rynkowych praktycznie od 1989 roku, świadcząc usługi w sektorze prywatnym. Z kolei dla większości podmiotów sektora publicznego wprowadzany od 1996 roku system kontraktów stał się nowym doświadczeniem wymuszającym zmiany nie tylko stricte zarządcze, ale i organizacyjne oraz kulturowe. Imperatyw zapewniania wysokiej jakości świadczeń zdrowotnych oraz doskonalenia metod pracy miał stać się udziałem podmiotów zarówno sektora prywatnego, jak i publicznego. Jednocześnie ekonomizacja działań placówek ochrony zdrowia na plan pierwszy - przynajmniej w warstwie deklaratywnej - wysunęła kwestię skuteczności i efektywności podejmowanych aktywności, ze szczególnym uwzględnieniem rachunku kosztów. Z drugiej strony, przegląd piśmiennictwa, jak i doświadczenia innych państw wskazują, że osiąganie optymalnych (z punktu widzenia efektów zdrowotnych i kosztów) wyników w opiece nad chorym pozostaje pod wypływem wielu czynników, z których nie wszystkie mają charakter ilościowy (tak jak np. ilość zużytych leków). Równie istotne są zmienne jakościowe sensu largo tworzące kulturę organizacji. To one bowiem wpływają na jakość funkcjonalną świadczonych usług i decydują o atmosferze, w jakiej przebiegajac diagnoza, terapia i rehabilitacja pacjenta. Stad interesujacym problemem badawczym jest uchwyce- nie ewentualnych różnic $w$ kulturze organizacji w obu typach podmiotów. Zagadnienie to, obecne w polu zainteresowania środowisk akademickich, głównie w Stanach Zjednoczonych ${ }^{1)}$, w polskiej literaturze nie było dotychczas poruszane.

Jako pierwszy pojęciem kultury organizacji posłużył się Elliot Jaques, prowadzący badania w fabryce Glacier $^{2}$. Do chwili obecnej powstało bardzo wiele interpretacji tego terminu ${ }^{3)}$, które nie odnoszą się do typu organizacji, lecz mają charakter uniwersalny. Stąd można przyjąć, że kulturą organizacji w zakładach opieki zdrowotnej będzie swoista konfiguracja norm, wartości, przekonań i zachowań opisujących sposób, w jaki działają członkowie danej placówki. Kultura organizacji w takim sensie jest swoistym wytworem grupowego doświadczenia i w związku z tym może zaistnieć tylko w obrębie zdefiniowanej grupy.

W sektorze ochrony zdrowia na szczególną uwagę zasługują funkcje wewnętrzne kultury organizacji, takie jak: zaspokajanie potrzeby bezpieczeństwa i afiliacji, określenie kryteriów nagradzania i karania czy zdefiniowanie granic grupy (kryteria przyjęcia i odrzucenia). Ich istotność podyktowana jest tym, że pracownicy opieki zdrowotnej spędzają w miejscu pracy często wiele czasu (dyżury), a jako przedstawiciele głównie zawodów medycznych wysoko cenią sobie etos pracy. Ponadto można stwierdzić, że profesje medyczne, zarówno przez samych ich przedstawicieli, jaki i w szerszym odbiorze społecznym, opatrzone sa niejako stygmatem służby i powołania. Stąd wykonywanie tego typu zawodów, a priori, motywowane jest w dużej mierze bodźcami pozafinansowymi. Abstrahujacc od ciaggle popularnego w zbiorowej świadomości modelu lekarza Judyma, od profesjonalistów medycznych wymaga się przyjęcia postawy zorientowanej na pomoc cierpiącemu człowiekowi i to niezależnie od stopnia ich motywacji finansowej. Stąd podejmowana w niniejszym artykule problematyka kultury organizacji w zakładach opieki zdrowotnej $\mathrm{w}$ dobie zmian systemowych opisywanych przede wszystkim pod hasłem „racjonalizacja działań” wydaje się interesującym i godnym uwagi tematem. 


\section{Metodologia badawcza}

W celu identyfikacji różnic międzygrupowych (publiczne versus niepubliczne podmioty opieki zdrowotnej) w obszarze kultury organizacji przeprowadzono badanie pierwotne. Zastosowano metodę wywiadu ze standaryzowanym kwestionariuszem ankiety, którym objęto świadczeniodawców usług zdrowotnych. Badanie miało charakter regionalny (woj. zachodniopomorskie) i zostało przeprowadzone w okresie listopad 2003-styczeń 2004 roku. Respondentów stanowili pracownicy medyczni zakładów opieki zdrowotnej. Dobór próby miał charakter losowy prosty zależny, co pozwoliło na oszacowanie statystycznego błędu przewidywania na poziomie 0,05 (dla poziomu ufności 0,95 ). Operat losowania stanowił rejestr zakładów opieki zdrowotnej województwa zachodniopomorskiego według stanu na 1 października 2003 $\mathrm{roku}^{4)}$. W badaniu wzięło udział 126 pracowników pionu medycznego zatrudnionych w placówkach ochrony zdrowia regionu ${ }^{5)}$, z których 56 miało status publiczny (SPZOZ), a 70 - niepubliczny (NZOZ).

\section{Statystyczna analiza wyników badań}

W celu odpowiedzi na powyżej sformułowane pytanie badawcze posłużono się analizą wariancji, w której za zmienną niezależną (klasyfikacyjna) przyjęto status zakładu opieki zdrowotnej (publiczny, niepubliczny). Zweryfikowano równość średnich w rozkładach warunkowanych kategoriami czynnika kontrolowanego (status zakładu). Przeprowadzone obliczenia pozwoliły na określenie statystycznie istotnych różnic między zakładami publicznymi i niepublicznymi dla kilku czynników opisujących kulturę organizacji (tab.).

Na podstawie tabeli można wnioskować, że statystycznie istotne różnice międzygrupowe istnieją dla wszystkich zmiennych (subskal kultury organizacji) poza zmiennymi I, N i P, przy czym średnie w prze- kroju podgrup (SPZOZ, NZOZ) wypadają w każdym przypadku korzystniej dla niepublicznych zakładów opieki zdrowotnej. Najbardziej wyraźne różnice istnieją dla zmiennych: „Wspieranie działań personelu medycznego przez kierownictwo”, „Zgodność wymagań kierownictwa z preferencjami personelu" oraz „Satysfakcja zawodowa”.

\section{Dyskusja}

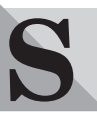

ilna kultura organizacji, jak dowodzą studia teoretyczne i empiryczne ${ }^{6)}$, jest istotnym czynnikiem wpływającym na pozytywny wynik pracy zespołowej, a poprzez to - na ekonomiczne efekty działalności zakładów opieki zdrowotnej. Wśród najważniejszych obszarów oddziaływania kultury organizacji wymienić można: podnoszenie poziomu jakości świadczonych usług, ułatwianie współpracy, wzbudzanie u chorego zaufania do pracowników, ułatwianie komunikacji w zespole, stymulowanie dobrej atmosfery w grupie pracowników ${ }^{7)}$.

W odniesieniu do zmian systemowych stających się udziałem również polskiego sektora zdrowia, szczególnie ważny jest wpływ kultury organizacji na jakość usług zdrowotnych i wydajność pracy personelu medycznego. Badania tematycznie zbliżone do zagadnienia podejmowanego w niniejszym artykule, a dotyczące szpitali amerykańskich wykazały, że wydajność pracy oddziałów i rozumienie wysokiej jakości opieki jest funkcją dobrego zarządzania konfliktami w zespole, w tym umiejętności porozumiewania się, rozwiązywania problemów oraz właściwego informowania pacjentów ${ }^{8)}$. Kultura organizacji tego typu, poprzez współuczestnictwo pracowników w zespole i stymulowanie ich zaangażowania, przyczynia się do wzrostu wartości relacji w układzie pacjent-personel medyczny ${ }^{9}$.

Posłużenie się w badaniu subskalą kultury organizacji według D. Rousseau pozwoliło na wychwycenie znaczenia trzech zasadniczych grup wartości:

- zorientowanych na zadania (zmienne H i I),

Tab. Analiza wariancji dotycząca poziomu kultury organizacji - różnice między zakładami publicznymi i niepublicznymi istotne przy $p<0,05$

\begin{tabular}{|l|c|c|c|c|}
\hline \multicolumn{1}{|c|}{ Subskale kultury organizacji według D. Rousseau } & Statystyka & $\begin{array}{c}\text { Poziom } \\
\text { istotności }\end{array}$ & $\begin{array}{c}\text { Średnia } \\
\text { SPZOZ } \\
\overline{\mathbf{X}}_{1}\end{array}$ & $\begin{array}{c}\text { Średnia } \\
\text { NZOZ } \\
\overline{\mathbf{X}}_{\mathbf{2}}\end{array}$ \\
\hline H. „Jasny podział ról i ich zrozumienie” & $\mathbf{4 , 7 2 3 9}$ & $\mathbf{0 , 0 3 1 6}$ & 3,911 & 4,286 \\
I. „Pacjent traktowany jest jak klient” & 2,3668 & 0,1264 & 3,446 & 3,786 \\
J. „Wspieranie działań personelu medycznego przez kierownictwo” & $\mathbf{1 4 , 8 3 0 7}$ & $\mathbf{0 , 0 0 1}$ & 3,179 & 4,029 \\
K. „Miła atmosfera w zespole” & $\mathbf{5 , 8 0 4 6}$ & $\mathbf{0 , 0 1 7 4}$ & 3,643 & 4,086 \\
L. „Zgodnó́ć wymagań kierownictwa z preferencjami personelu” & $\mathbf{1 1 , 5 8 2 2}$ & $\mathbf{0 , 0 0 7}$ & 3,179 & 3,871 \\
M. „Integracja personelu poza miejscem pracy” & $\mathbf{4 , 1 1 0 4}$ & $\mathbf{0 , 0 4 2}$ & 2,607 & 2,929 \\
N. „Poczucie bezpieczeństwa w miejscu pracy” & 1,8073 & 0,1801 & 3,214 & 3,457 \\
O. „Satysfakcja zawodowa” & $\mathbf{6 , 9 5 9 5}$ & $\mathbf{0 , 0 0 9 4}$ & 3,482 & 4,014 \\
P. „Zaangażowanie w pracę” & 0,7386 & 0,3917 & 4,643 & 4,534 \\
\hline
\end{tabular}

Źródło: opracowanie własne na podstawie wydruku z programu Statistica 6.0. 
- interpersonalnych (zmienne J, K, L i M),

- indywidualnych (zmienne N, O, P).

Wymienione subskale (wyróżniki kultury organizacji) mają charakter jakościowy i odnoszą się zarówno do pracy w zespole terapeutycznym, jak i do indywidualnych postaw i zachowań członków organizacji. Ich znaczenie - jak już sygnalizowano na wstępie w sektorze ochrony zdrowia wydaje się szczególnie cenne, głównie na skutek postawy pracowników medycznych, która wykracza poza motywacje stricte finansowe. Trzeba bowiem pamiętać, że motywator w postaci wynagradzania jest bodźcem egzogenicznym i jako taki często okazuje się mniej efektywny od motywacji wewnętrznej, a także może prowadzić do jej erozji $^{10)}$. Z kolei motywatory wewnętrzne (zmienne J-P) mają charakter trwalszy i przynoszą efekty w dłuższym czasie. I choć nie noszą one cech nagród, to ich siłą jest opieranie się na potrzebach i preferencjach klienta wewnętrznego, jakim niewątpliwe jest pracownik każdej organizacji. Ich rozpoznanie powinno być punktem wyjścia w procesie marketingu wewnętrznego. Umożliwienie pracownikom zakładów opieki zdrowotnej artykulacji własnych preferencji i, co bardzo istotne, ich uwzględnianie w codziennej pracy, jest elementem konstruujaccym silną kulturę organizacji. Długotrwałe modelowanie postaw i zachowań personelu w kierunku sprzyjającym osiąganiu lepszych efektów gospodarowania ograniczonymi zasobami ochrony zdrowia jest bowiem możliwe do osiagnięcia tylko przy współudziale samych pracowników. W przeciwieństwie do motywatorów zewnętrznych oddziałujących tylko w momencie aktywności danego instrumentu (jak nagroda czy kara) bodźce zorientowane na budowę poczucia bezpieczeństwa w miejscu pracy, tworzenie klimatu prywatności i otwartej komunikacji sprzyjają kreacji więzi z pracodawcą. Znaczenia tego elementu nie sposób pominąc szczególnie w sektorze usług profesjonalnych, gdzie reputacja usługodawcy (tu: głównie lekarzy) często powoduje transfer usługobiorców (tu: pacjentów) wraz ze zmianą miejsca pracy danego profesjonalisty.

W przeprowadzonym badaniu pierwotnym z przekrojów statystyk opisowych (wartości średnie w podgrupach SPZOZ i NZOZ) wynika, że korzystniejszy klimat do formowania wartości poprzez kulturę organizacji mają zakłady niepubliczne. Odnosi się to do sfery relacji międzyludzkich - zarówno na poziomie podwładny-przełożony, jak i na poziomie zespołu terapeutycznego. W zakładach niepublicznych średnie oceny dotyczące stosunków wynikających z hierarchii zawodowej (zmienne: „Jasny podział ról i ich zrozumienie”, „Zgodność wymagań kierownictwa z preferencjami personelu”, „Wspieranie działań personelu medycznego przez kierownictwo") były wyższe w porównaniu z tymi uzyskanymi w zakładach publicznych. Podobne rezultaty - na korzyść zakładów niepublicznych - uzyskano oceniając atmosferę panującą w zespole i jego skłonność do integrowania się poza miejscem pracy (zmienne: „Miła atmosfera w zespole”, „Integracja personelu poza miejscem pracy”). Budowanie więzi społecznych, poza funkcją motywacyjną, stanowi istotny element sprzyjający kreacji wartościowej relacji z klientami (tu: pacjentami), szczególnie poprzez podnoszenie jakości funkcjonalnej procesu świadczenia usługi zdrowotnej. Liczne badania empiryczne $^{11)}$ wskazują, że takie charakterystyki personelu medycznego, jak: empatia wobec pacjentów, łatwość nawiązania komunikacji, życzliwość, grzeczność, zaangażowanie, gotowość do niesienia pomocy czy poszanowanie intymności pacjenta należą do najbardziej cenionych w odbiorze pacjentów.

Z zaprezentowanych badań wynika jednoznacznie, że satysfakcja zawodowa pracowników medycznych zatrudnionych w zakładach o statusie niepublicznym jest wyższa od tej odczuwanej przez personel zakładów publicznych. Zagadnienie to jest głębsze niż tylko i wyłącznie system wynagrodzeń z tytułu umowy/ kontraktu o pracę. Obejmuje bowiem również system nagród i wyróżnień, ścieżkę awansu zawodowego, szkolenia profesjonalne, rozwój naukowy, budowę więzi społecznych czy budowanie poczucia stabilności pracy. W tym ostatnim przypadku - według przeprowadzonego badania regionalnego - między analizowanymi podgrupami zakładów nie odnotowano statystycznie istotnych różnic. W odniesieniu do zmiennej „Poczucie bezpieczeństwa w miejscu pracy” zauważono co prawda wyższa średnią dla zakładów niepublicznych, ale w porównaniu z placówkami sektora publicznego nie była to różnica znaczna. Na szczególną uwagę zasługuje również fakt, że dla subskali „Zaangażowanie w pracę" - bez statystycznie istotnych różnic międzygrupowych - jako jedyny przypadek w całym badaniu, to zakłady publiczne okazały się mieć nieznacznie wyższą średnią od placówek sektora niepublicznego. Można zatem wyciągnąc wniosek, że w pracownikach medycznych sektora publicznego drzemie duży potencjał, którego uaktywnienie wymagać będzie zastosowania odpowiednich bodźców motywacyjnych. Oznacza to zarazem, że kultura organizacji i jej poszczególne składowe nie poddają się schematycznym manipulacjom, a wręcz przeciwnie - wymagaja precyzyjnego dopasowania do specyfiki podsektorów (niepubliczny versus publiczny).

\section{Wnioski końcowe}

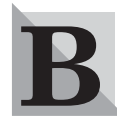
iorac pod uwagę unikatową cechę sektora zdrowia przejawiajacca się w tzw. indukowaniu popytu przez podaż ${ }^{12)}$, związek pacjentusługodawca jest w przeważającej mierze efektem oddziaływania strony podażowej. To, jak owa relacja ukształtuje się w sektorze zdrowia, zależy nie tylko od uwarunkowań zewnętrznych (jak system prawny, skala wydatków publicznych na zdrowie, stopień liberalizacji systemu ochrony zdrowia), ale i od tego, jaka kultura panuje w zakładzie opieki zdrowotnej oraz jaki system bodźców motywuje usługodawców do efektywnego działania ${ }^{13)}$. Silna kultura sprzyja bowiem efektywności funkcjonowania organizacji poprzez usprawnienie komunikacji, sprawniejsze podejmowanie decyzji i wdrażanie rozwiązań - pracownicy podzielając określone wartości szybciej dochodzą do kon- 
sensusu. Kreacja więzi typu wspólnotowego oraz zaszczepianie pracownikom norm i wartości tożsamych dla danej organizacji ukierunkowują i pobudzają działania personelu, przez co spada znaczenie formalnych sposobów zapewniania zgodności tych działań z celami podmiotu.

Po wtóre, silna kultura organizacji zapewnia jej członkom poczucie afiliacji i identyfikacji, co sprzyja budowaniu lojalności wobec zakładu pracy, a poprzez to i jego efektywnemu działaniu. Odpowiedni system motywacji dostawców świadczeń medycznych związany de facto z systemem wartości wytworzonych i kultywowanych w organizacji sprzyja nie tylko realizacji ich misji, ale i wpływa na skuteczność funkcjonowania rynku usług zdrowotnych. Dzieje się tak dlatego, że stopień konkurencyjności usługodawców pozostaje w ścisłym związku z siłą motywacji tych podmiotów do efektywnego działania. Z kolei ono ma decydujący wpływ na relację $\mathrm{z}$ pacjentami kształtowaną przez usługodawców.

Z przeprowadzonych badań empirycznych wynika, że status zakładu opieki zdrowotnej różnicuje kulturę organizacyjna w prezentowanych typach podmiotów. Warto przy tym podkreślić, że wywiady były prowadzone tylko wśród pracowników zatrudnionych w danej placówce na pierwszym etacie lub na kontrakcie, co w zasadzie redukuje prawdopodobieństwo wzajemnego „przenikania” się strumieni pracy zawodowej w obu typach zakładów jednocześnie. Wyniki eksploracji tworzą zatem wiarygodny obraz różnic w kulturze organizacji, kwestionując jednocześnie obiegową opinię o rzekomej przewadze podmiotów niepublicznych tylko na skutek wyższego poziomu wynagrodzeń. Uogólniając można stwierdzić, że podmioty sektora niepublicznego, biorąc pod uwage ich stosunek do pracowników, są bardziej dostosowane do wymogów konkurowania na rynku usług medycznych. Wydają się one dostrzegać zależność polegającą na tym, że satysfakcja pacjenta jest w dużej mierze pochodna satysfakcji pracownika. Zaadaptowanie tej prostej reguły z trudnością przychodzi większości badanych podmiotów publicznych.

\section{Zakończenie}

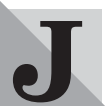

ednym z dogmatycznych założeń popularnych wśród wielu badaczy sektora ochrony zdrowia jest twierdzenie o wyższości własności prywatnej nad publiczną ${ }^{14)}$. Przewaga ta przejawiać się ma w większej konkurencyjności sektora niepublicznego i jego zdolności do doskonalenia jakości usług zdrowotnych. Jednak, jak dotychczas, brak jest dowodów empirycznych jednoznacznie potwierdzających większą efektywność niepublicznych podmiotów opieki zdrowotnej w porównaniu z publicznymi. Przeprowadzone badanie wykazało, że forma własności wpływa na zróżnicowanie poziomu kultury organizacyjnej w obu typach podmiotów, przy czym przewaga leży po stronie zakładów niepublicznych. W tej perspektywie interesujące wydaje się zastosowanie w placówkach publicznych bodźców kreujących silną kulturę organizacji, stosowanych dotychczas z powodzeniem w placówkach niepublicznych, jak i ocena ich oddziaływania na efektywność funkcjonowania zakładów.

dr Iga Rudawska

Katedra Marketingu

Uniwersytet Szczeciński

Artykut powstat $w$ ramach projektu badawczego (nr 2H02C 034 25) finansowanego ze środków KBN $w$ latach 2003-2005, którego autorka jest kierownikiem.

\section{PRZYPISY}

1) Zob. m.in. E.S. SAVAS, Prywatyzacja. Klucz do lepszego rzadzenia, PWE, Warszawa 1992, s. 125.

2) J. WACŁAW, Kultura organizacyjna $i$ wewnętrzna komunikacja marketingowa - wzajemne powiazania, „Antidotum" 2003, nr 8, s. 4

3) Zob. m.in. L. ZBIEGIEŃ-MACIĄG, Kultura $w$ organizacji. Identyfikacja kultury znanych firm, PWN, Warszawa 1999.

4) Rejestr zakładów opieki zdrowotnej jest dostępny na stronach internetowych www.rejestrzoz.gov.pl.

5) Chodzi tu o osoby zatrudnione na pierwszym etacie w poszczególnych placówkach.

6) Zob. m.in. A.M. WILSON, The Nature of Corporate..., op.cit., s. 87-99.

7) Por. L. SIERPIŃSKA, A. KSYKIEWICZ-DOROTA, Wptyw kultury organizacji na prace zespotu terapeutycznego, „Zdrowie Publiczne” 2001, nr 111 (5-6), s. 308.

8) S.M. SHORTELL, A.D. KALUZNY, Podstawy zarzadzania opieka zdrowotna, Wyd. Vesalius, Kraków 2001, s. 417.

9) Chodzi tu przede wszystkim o lekarzy, ale także o personel medyczny średniego szczebla, jak pielęgniarki, położne, technicy medyczni i laboranci.

10) J. KLICH, Motywowanie finansowe personelu, „Zdrowie i Zarzadzanie" 2004, nr 1, tom IV, s. 16.

11) Zob. m.in. J.M. ALDANA, A. Al.-SABIR, H. PIECHULEK, Client Satisfacion and Quality of Health Care in Rural Bangladesch, „Bulletin of the WHO” 2001, nr 79 (6); R. JOHNSTON, The Determinant of Service Quality: Satisfiers and Dissatisfiers, „International Journal of Service Industry Management" 1995, vol. 6, nr 5.

12) Szerzej na ten temat zob. T.E. GETZEN, Ekonomika zdrowia. Teoria i praktyka, Wydawnictwo Naukowe PWN, Warszawa 2000.

13) Teza o istnieniu związku między silną kulturą organizacyjną a efektywnością funkcjonowania podmiotu została rozwinięta m.in. w bestsellerze T. PETERSA i R. WATERMANA pt. In Search of Excellence. Podano za: Zdrowie $i$ jego ochrona. Między teoria a praktyka, red. V. KORPOROWICZ, Wyd. SHG, Warszawa 2004, s. 69.

14) Zob. An Introduction to Health Economics for Eastern Europe and the Former Soviet Union, red. S. WITTER, T. ENSON, J. Wiley\&Sons, Chichester 1997, s. 173.

\section{BIBLIOGRAFIA}

[1] An Introduction to Health Economics for Eastern Europe and the Former Soviet Union, red. S. WITTER, T. ENSON, J. Wiley\&Sons, Chichester 1997.

[2] GETZEN T.E., Ekonomika zdrowia. Teoria i praktyka, Wydawnictwo Naukowe PWN, Warszawa 2000.

[3] RÓSZKIEWICZ M., Metody ilościowe w badaniach marketingowych, PWN, Warszawa 2002.

[4] SHORTELL S.M., KALUZNY A.D., Podstawy zarzadzania opieka zdrowotna, Wyd. Vesalius, Kraków 2001.

[5] WILSON A.M., The Nature of Corporate Culture within a Service Delivery Environment, „International Journal of Service Industry Management” 1997, vol. 8, nr 1. 